\title{
Sesquiterpenes and Other Natural Products from Roldana reticulata
}

\author{
Amira Arciniegas, ${ }^{1}$ Jhon Ironzi Maldonado, ${ }^{1}$ Karina González, ${ }^{1}$ Ana L. Pérez-Castorena, ${ }^{1} *$ José Luis \\ Villaseñor, ${ }^{2}$ Alfonso Romo de Vivar $^{1}$ \\ ${ }^{1}$ Instituto de Química, and ${ }^{2}$ Instituto de Biología, Universidad Nacional Autónoma de México, Circuito Exterior, Ciudad \\ Universitaria, Coyoacán 04510,D.F., México.alperezc@unam.mx
}

Received October 10, 2012; accepted January 30, 2013

\begin{abstract}
Resumen. De Roldana reticulata se aislaron dos 9-oxo-furanoeremofilanos $(\mathbf{1}, \mathbf{2})$, además de senecrassidiol, tirosol, icarisida $\mathrm{D}_{2}$ y rutina; no se detectaron alcaloides pirrolizidínicos, coincidiendo con el patrón químico del género reportado hasta ahora. La actividad anti-inflamatoria de los extractos y productos aislados fue evaluada en el modelo de edema de inflamación aguda inducido con TPA.

Palabras clave: Roldana reticulata, Asteraceae, Senecioneae, Tussilagininae, furanoeremofilanos, actividad anti-inflamatoria.
\end{abstract}

\section{Introduction}

Roldana reticulata is one of the 48 species of the genus Roldana (Asteraceae, Senecioneae, Tussilagininae) which groups species segregated mainly from the genus Senecio, spread from southern Arizona and New Mexico to Panama [1, 2]. Some species of Roldana are known to have medicinal properties; $R$. sessilifolia is used as part of the "cachani" complex [3], in Mexican traditional medicine to treat female sterility, hemorroids and rheumathic pains, and $R$. ehrenbergiana (Itzcuimpatli or hierba de perro) has been used to treat leprosy [4]. Products with anti-oxidant, anti-inflammatory and insecticidal properties have been isolated from $R$. barba-johannis [5], while bioactive metabolites against Trichophyton mentagrophytes have been isolated from $R$. lineolata [6]. Previous phytochemical reports have shown that eremophilane derivatives are the main secondary metabolites isolated from eight of the ten species of this genus studied so far: $R$. angulifolia [7], R. aschenborniana (also studied as Senecio aschenbornianus) [8, 9], R. ehrenbergiana [10], R. heterogama [11], $R$. lineolata [6], R. lobata [12], $R$. sessilifolia [13], and R. barba-johannis (also studied as Senecio barba-johannis) [5]. The phytochemical studies of $R$. mexicana (studied as Senecio mexicanus) and $R$. sundbergii (studied as Senecio sundbergii) report the isolation of opoplane sesquiterpenes [14], caryophyllene, and open chain sesquiterpenes [9], respectively. This paper describes the first chemical study of Roldana reticulata.

\section{Results and Discussion}

The chemical study of roots and aerial parts of Roldana reticulata afforded two 9-oxofuranoeremophilanes (1 and 2) $[9,15]$, tyrosol (3) [16], icarioside $\mathrm{D}_{2}$ (4) [17], senecrassidiol (5) [18], rutin (6) [19], sucrose, a mixture of $\beta$-sitosterol-stigmasterol, and $\beta$-sitosteryl glucopyranoside. Structures of the
Abstract. The chemical study of Roldana reticulate led to the isolation of two 9-oxo-furanoeremophilanes $(\mathbf{1}, \mathbf{2})$, together with senecrassidiol, tyrosol, icariside $\mathrm{D}_{2}$, and rutin; no pyrrolizidine alkaloids were detected, in agreement with the chemistry of the genus reported so far. The anti-inflammatory activity of extracts and isolated products was tested using the TPA model of induced acute inflammation.

Key words: Roldana reticulata, Asteraceae, Senecioneae, Tussilagininae, furanoeremophilanes, anti-inflammatory activity.

isolated products were determined by comparing their physical constants and spectroscopic data with those reported in the literature. The ${ }^{13} \mathrm{C}$ NMR data of $6 \beta$-(2-methyl-2-vinylacetoxy)furanoeremophil-9-one (1) are included because they are not yet available in the literature. Assignments were achieved by means of 1D and 2D NMR. The characteristic signals of the carbonyl groups, a conjugate ketone at $\delta 186.7$ and an ester function at $\delta 173.9$ were evident. The HMBC correlations of $\mathrm{H}-$ 10 and $\mathrm{H}-1$ with the first one allowed to position the ketone at C-9 and the interaction of H-6 with the second one determined the position of the ester group at C-6. Additionally, the presence of four aromatic and two vinyl carbon atoms accounted for the furan ring and the vinyl acetoxy substituent.

Due to the medicinal use of some Roldana species [3, 5], the anti-inflammatory activity of extracts and isolated products of $R$. reticulata were evaluated using the $12-O$-tetradecanoylphorbol-13-acetate (TPA) model of induced acute inflammation [20]. All extracts, with exception of the methanol extract of the roots which was not active, were moderately active showing values between 35.41 to $64.75 \%$ of inhibition (Table 1), being more active those of the aerial parts. None of the isolated metabolites showed relevant activity compared with indomethacin, the reference compound.

The results of the phytochemical study of $R$. reticulata, showing the presence of furanoeremophilanes and phenolic products and the fact that pyrrolizidine alkaloids were not detected, nor isolated, coincide with the chemistry of the genus and of the tribe Senecioneae and subtribe Tussilagininae [21].

\section{General Experimental Procedures}

Melting points were determined using a Fisher Jones melting point apparatus and are uncorrected. IR spectra were recorded on a Nicolet Magna-IR 750 spectrometer. EIMS data were 
Table 1. Effect of extracts and isolated products from $R$. reticulata on TPA-induced mouse edema

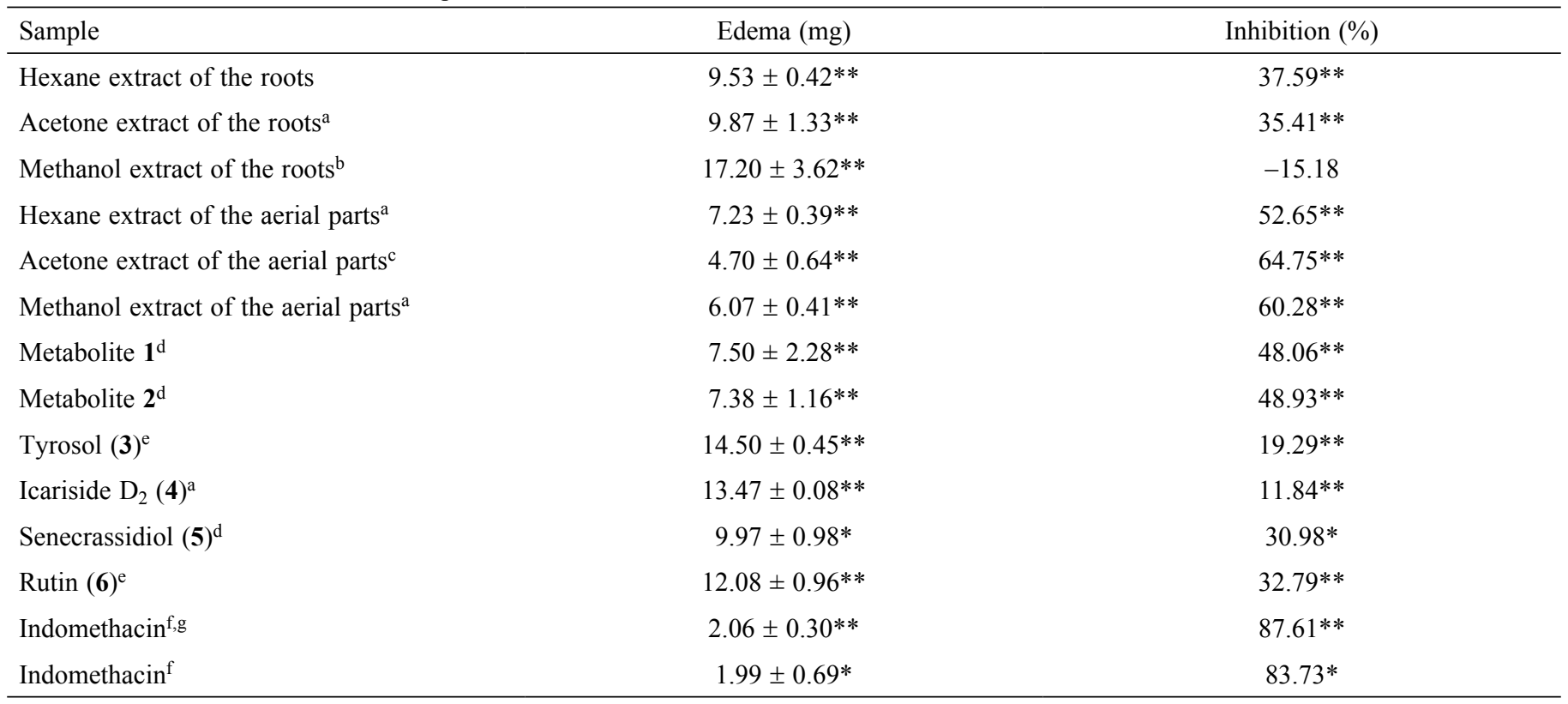

Dose: $1 \mathrm{mg} / \mathrm{ear}$ for extracts, $1 \mu \mathrm{mol} / \mathrm{ear}$ for pure compounds. Each value represents the mean of three animals \pm standard error. Control: ${ }^{a}$ methanol-acetone 1:1, $15.28 \pm 0.29$; ${ }^{b}$ methanol $14.93 \pm 0.52{ }^{c}$ acetone- $\mathrm{CH}_{2} \mathrm{Cl}_{2}$ 1:1, $13.33 \pm 0.66,{ }^{\mathrm{d}}$ acetone- $\mathrm{CH}_{2} \mathrm{Cl}_{2} 1: 1 \quad 14.44 \pm 0.61,{ }^{\mathrm{e}}$ methanol $17.97 \pm 0.48$, ${ }^{\mathrm{f}}$ acetone, $13.53 \pm 104,{ }^{\mathrm{g}} 1 \mathrm{mg} /$ ear. Results were analysed by the $t$ Student test. ${ }^{*} p \leq 0.05 .{ }^{* *} p \leq 0.01$.

determined on a JEOL JMS-AX505HA mass spectrometer at $70 \mathrm{eV} .{ }^{1} \mathrm{H}$ NMR and ${ }^{13} \mathrm{C}$ NMR data were obtained on a Varian Unity 300 or on a Varian Unity Plus 500 instrument. Chemical shifts were referred to TMS. Preparative HPLC was carried out in a Waters Delta Prep 4000 instrument using a Luna $5 \mathrm{u}$ C18(2) 100A, AXIA packed column of $50 \times 21.2 \mathrm{~mm}$ at 20 $\mathrm{ml} / \mathrm{min}$, Detector UV Waters 486 at $280 \mathrm{~nm}$. Vacuum column chromatography (VCC) was performed using Silica gel $60 \mathrm{G}$ (Merck, Darmstadt, Germany). Flash column chromatography (FCC) was run using Silica gel 60 (230-400 Macherey-Nagel). TLC was carried out on Silica gel $60 \mathrm{GF}_{254}$ and preparative TLC on Silica gel $\mathrm{GF}_{254}$ (Macherey-Nagel), layer thickness $2.0 \mathrm{~mm}$.

\section{Plant Material}

Roldana reticulata (DC.) H. Rob. \& Bretell was collected at Llano de la Cantimplora, Tlalpan, México D. F., México, in December 2003. A voucher specimen was deposited at the Herbarium del Instituto de Biología, UNAM, México (MEXU 1156423).

\section{Extraction and Isolation}

Dried and ground roots (383 g) and aerial parts (569 g) of $R$. reticulata were separately and successively extracted with hexane, acetone and methanol. Solvents were removed at reduced pressure to obtain the corresponding extracts which gave negative tests with the alkaloids Dragendorff reagent. The hexane extract of the roots (12 g) was subjected to VCC eluting with hexane-EtOAc mixtures of increasing polarity. Fractions eluted with hexane-EtOAc 19:1 (2.5 g) were further purified by a VCC (hexane-EtOAc 49:1) and FCC (hexane-EtOAc 19:1) to produce a mixture (680 $\mathrm{mg}$ ) which was purified by HPLC (MeOH- $\left.\mathrm{H}_{2} \mathrm{O} 70: 30\right)$ to yield 1 (8 mg, colorless gum, $[\alpha]_{25}$ $-40.5^{\circ}, c 0.25, \mathrm{CHCl}_{3}$, ) [9] and 2 (5.6 mg, colorless needles, mp 103-105 ${ }^{\circ} \mathrm{C},[\alpha]_{25}-90.2^{\circ}, c 0.2, \mathrm{CHCl}_{3}$, lit.: $[\alpha]_{25^{-}}-90.3^{\circ}$, $c 0.4, \mathrm{Me}_{2} \mathrm{CO}$ ) [15]. The acetone extract of the roots $(5.6 \mathrm{~g})$ was purifiedby $\mathrm{VCC}$ eluting with hexane-acetone mixtures of increasing polarity to obtain $25 \mathrm{mg}$ of icariside $\mathrm{D}_{2}(4)(9.5 \mathrm{mg}$, amorphous powder, $[\alpha]_{25}-59.5^{\circ}, c 0.1, \mathrm{MeOH}$, lit.: $[\alpha]_{25}-61.9^{\circ}$, $c 0.11, \mathrm{MeOH}$ ) [17] from the hexane-acetone 3:2 eluates. The methanol extract of the roots $(24 \mathrm{~g})$ was fractionated by VCC eluting with EtOAc-MeOH mixtures of increasing polarity to produce sucrose $(350 \mathrm{mg})$ and $\beta$-sitosteryl glucopyranoside (180 mg, amorphous powder). Successive VCC purifications of the hexane extract of the aerial parts (12.7 g) using hexane-EtOAc mixtures of increasing polarity as eluent produced senecrassidiol (5) (9 mg, colorless needles, 93-95 ${ }^{\circ} \mathrm{C},[\alpha]_{25}$ $10.1^{\circ}, c 0.1, \mathrm{CHCl}_{3}$, lit.: $\left.[\alpha]_{24}-10.9^{\circ}, c 0.23, \mathrm{CHCl}_{3}\right)[18]$ and a mixture of $\beta$-sitosterol and stigmasterol ( $23 \mathrm{mg}$, colorless plats,

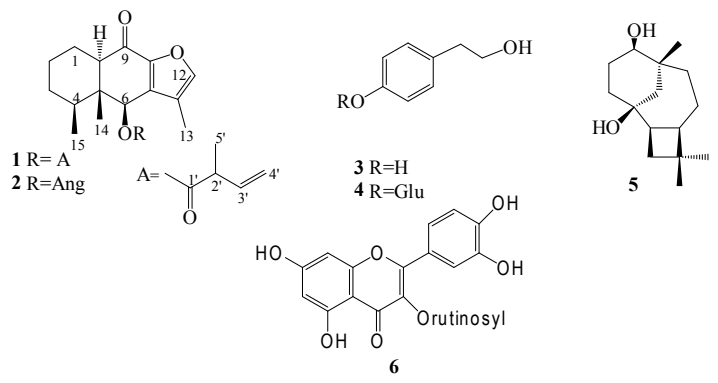


mp $130-132{ }^{\circ} \mathrm{C}$ ). Similarly, the VCC purification (hexane-acetone mixtures of increasing polarity) of the acetone extract of the aerial parts $(35 \mathrm{~g})$ resulted in fractions: A (eluted with hexane-acetone 9:1), B (eluted with hexane-acetone 4:1 and 7:3), and $C$ (eluted with hexane-acetone $3: 2$ and 1:1). Purification of fraction A (5.6 g) by FCC (hexane-acetone 9:1) produced mixture of $\beta$-sitosterol-stigmasterol (36 mg). Fraction B (8.5 g) was purified by FCC (hexane-acetone 7:3) to yield $8 \mathrm{mg}$ of tyrosol (3) as colorless needles ( $\left.\mathrm{mp} 89-91{ }^{\circ} \mathrm{C}\right)$ [16] and $85 \mathrm{mg}$ of icariside $\mathrm{D}_{2}$ (4). Fraction $\mathrm{C}$ produced an amorphous solid $(1.3 \mathrm{~g})$ which, by recrystallization (EtOAc- $\mathrm{MeOH})$, afforded $458 \mathrm{mg}$ of icariside $\mathrm{D}_{2}(4)$. The methanol extract of the aerial parts $(24 \mathrm{~g})$ was purified by VCC (EtOAc-MeOH mixtures of increasing polarity); while fractions eluted with EtOAc afforded $165 \mathrm{mg}$ of 4, the EtOAc-MeOH 9:1, 4:1 and 7:3 eluates afforded a mixture $(11 \mathrm{~g})$, a portion of which $(2 \mathrm{~g})$ was passed through a Sephadex LH 20 column $\left(\mathrm{MeOH}-\mathrm{H}_{2} \mathrm{O}\right.$ 4:1) to obtain $1.2 \mathrm{~g}$ of sucrose and $65 \mathrm{mg}$ of rutin (6) (yellow powder, $[\alpha]_{25}-3.0^{\circ}, c 0.25, \mathrm{MeOH}$, lit.: $\left.[\alpha]_{25}-8.8^{\circ}, c 0.14, \mathrm{MeOH}\right)$ [19].

63-(2-Methyl-2-vinylacetoxy)-furanoeremophil-9-one (1): ${ }^{13} \mathrm{C}$ NMR (CDCl $\left.3,125 \mathrm{MHz}\right): \delta 186.7$ (C, C-9), 173.9 (C, C1'), 146.9 (C, C-8), 144.9 (CH, C-12), 136.2 (CH, C-3'), 134.3 (C, C-7), 120.8 (C, C-11), $116.7\left(\mathrm{CH}_{2}, \mathrm{C}-4^{\prime}\right), 75.9(\mathrm{CH}, \mathrm{C}-6)$, $55.2(\mathrm{CH}, \mathrm{C}-10), 49.9$ (C, C-5), $44.4\left(\mathrm{CH}, \mathrm{C}-2^{\prime}\right), 42.5(\mathrm{CH}$, C-4), $32.2\left(\mathrm{CH}_{2}, \mathrm{C}-1\right), 24.9\left(\mathrm{CH}_{2}, \mathrm{C}-2\right), 20.7\left(\mathrm{CH}_{2}, \mathrm{C}-3\right), 18.6$ $\left(\mathrm{CH}_{3}, \mathrm{C}-15\right), 16.2\left(\mathrm{CH}_{3}, \mathrm{C}-5^{\prime}\right), 8.8\left(\mathrm{CH}_{3}, \mathrm{C}-13\right), 7.2\left(\mathrm{CH}_{3}\right.$, C-14).

\section{Evaluation of the anti-inflammatory activity}

Animals. Male NIH mice weighing 25-30 g were maintained under standard laboratory conditions in the animal house (temperature $27 \pm 1{ }^{\circ} \mathrm{C}$ ) with a $12 / 12 \mathrm{~h}$ light-dark cycle, according with the Mexican official norm MON-062-Z00-1999. They were fed laboratory diet and water ad libitum.

\section{TPA-induced edema model}

The TPA-induced ear edema assay in mice was performed as previously reported [20]. A solution of TPA $(2.5 \mu \mathrm{g})$ in ethanol $(10 \mu \mathrm{l})$ was applied topically to both faces $(5 \mu \mathrm{l}$ each face $)$ of the right ear of the mice. Solutions of the test substances in their respective solvents were applied 10 minutes after $(10 \mu \mathrm{l}$, to each face). The left ear received ethanol (10 $\mu \mathrm{l})$ first and ten minutes after $20 \mu \mathrm{l}$ of the respective solvent. Four hours later, the mice were killed by cervical dislocation. A $7 \mathrm{~mm}$ diameter plug was removed from each ear and the swelling was assessed as the difference in weight between the left and the right ear. Control animals received the correspondent solvent in each case. Edema inhibition (EI \%) was calculated by the equation: $\mathrm{EI}=100-(\mathrm{B} \times 100 / \mathrm{A})$, where $\mathrm{A}$ is the edema induced by TPA alone and $\mathrm{B}$ is the edema induced by TPA plus sample. Indomethacin was used as the reference compound (Table 1).

\section{Acknowledgements}

We are indebted to Antonio Nieto, Rubén Gaviño, Ma. de los Angeles Peña, Elizabeth Huerta, Isabel Chávez, Héctor Ríos, Beatriz Quiroz, Nieves Zavala, Rocío Patiño, Javier Pérez, Luis Velasco, Carmen Márquez, and Eréndira García for technical assistance.

\section{References}

1. Robinson, H.; Brettell, R. D. Phytologia 1974, 27, 402-439.

2. Fuston, A. A revision of the genus Roldana. Ph.D. Thesis, Kansas State University, Manhattan, KS, 1999.

3. Linares, E.; Bye, R. A. J. Ethnopharmacol. 1987, 19, 153-183.

4. Martínez, M. Las Plantas medicinales de México, Ed. Botas, México, 1959, p. 176.

5. a) Pérez-Castorena, A. L.; Arciniegas, A.; Ramírez-Apan, M. T.; Villaseñor, J. L.; Romo de Vivar, A. Planta Med. 2002, 68, 645647. b) Céspedes, C. L.; Torres, P.; Marín, J. C.; Arciniegas, A.; Romo de Vivar, A.; Pérez-Castorena, A. L.; Aranda, E. Phytochemistry 2004, 65, 1963-1975. c) Burgueño, E.; Gonzalez-Coloma, A.; Martín-Benito, D.; Joseph-Nathan, P. Z. Naturforsch. 2007, 62c, 362-366.

6. Arciniegas, A.; Pérez-Castorena, A. L.; Maldonado, J.; Avila, G.; Villaseñor, J. L.; Romo de Vivar, A. Fitoterapia 2008, 79, 4752.

7. Arciniegas, A.; Pérez-Castorena, A. L.; Villaseñor, J. L.; Romo de Vivar, A. J. Nat. Prod. 2006, 69, 1826-1829.

8. Arciniegas, A.; Pérez-Castorena, A. L.; Villaseñor, J. L.; Romo de Vivar, A. Biochem. Syst. Ecol. 2004, 32, 615-618.

9. Mericli, A. H.; Mericli, F.; Jakupovic, J.; Bohlmann, F.; Domínguez, X. A.; Vega, H. S. Phytochemistry 1989, 28, 1149-1153.

10. a) Pérez-Castorena, A. L.; Arciniegas, A.; Hernández, M. L.; De la Rosa, I.; Contreras, J. L.; Romo de Vivar, A. Z. Naturforsch. 2005, 60b, 1088-1092. b) Pérez-Castorena, A. L.; Arciniegas, A.; Hernández, M. L.; Toscano, R. A.; Contreras, J. L.; Romo de Vivar, A. J. Mex. Chem. Soc. 2006, 50, 157-159.

11. Bohlmann, F.; Zdero, C. Phytochemistry 1978, 17, 565-566.

12. Maldonado, J.; Arciniegas, A.; Pérez-Castorena, A. L.; Arciniegas, M.; Villaseñor, J. L.; Romo de Vivar, A. Z. Naturforsch. 2008, $63 b, 331-334$.

13. a) Delgado, G.; García, P. E.; Bye, R. A.; Linares, E. Phytochemistry 1991, 30, 1716-1719. b) Delgado, G.; García, P. E. Planta Med. 1993, 59, 389.

14. a) Joseph-Nathan, P.; Villagómez, J. R.; Román, L. U.; Hernández, J. D. Phytochemistry 1990, 29, 977-979. b) Joseph-Nathan, P.; Villagómez, J. R.; Rojas-Gardida, M.; Román, L. U.; Hernández, J. D. Phytochemistry 1989, 28, 2397-2401.

15. De Bernardi, M.; Vidari, G.; Vita-Finzi, P.; Abdo, S.; Marioni, G.; Mellerio, G. Gazz. Chim. Ital. 1988, 118, 565-568.

16. Park, C. H.; Kim, K. H.; Lee, I. K.; Lee, S. Y.; Choi, S. U.; Lee, J. H.; Lee, K. R. Arch. Pharm. Res. 2011, 34,1289-1296.

17. Miyase, T.; Ueno, A.; Takizawa, N.; Kobayashi, H.; Oguchi, H. Phytochemistry 1989, 28, 3483-3485.

18. Bohlmann, F.; Ziesche, J. Phytochemistry 1981, 20, 469-472.

19. Han, J.-T.; Bang, M.-H.; Chun, O.-K.; Kim, D.-O.; Lee, C.-Y.; Baek, N.-I. Arch. Pharm. Res. 2004, 27, 390-395.

20. Arciniegas, A.; Pérez-Castorena, A. L.; Nieto-Camacho, A.; Villaseñor, J. L.; Romo de Vivar, A. J. Mex. Chem. Soc. 2009, 53, 229-232.

21. Romo de Vivar, A.; Pérez-Castorena, A. L.; Arciniegas, A.; Villaseñor, J. L. J. Mex. Chem. Soc. 2007, 51, 160-172. 